\title{
Ruminal protein and fibre degradability of lucerne hay as affected by regrowth period and dairy breed
}

\author{
C.W. Cruywagen ${ }^{1}$, C.J.C. Muller ${ }^{2 \#} \&$ F.J. du Toit ${ }^{1,3}$ \\ ${ }^{1}$ Department of Animal Sciences, Stellenbosch University, Private Bag X1, Matieland 7602, South Africa \\ ${ }^{2}$ Department of Agriculture: Western Cape, Institute for Animal Production, Private Bag X1, Elsenburg 7607, South \\ Africa \\ ${ }^{3}$ Present address: Nova Feeds, P.O. Box 700, Malmesbury 7299, South Africa
}

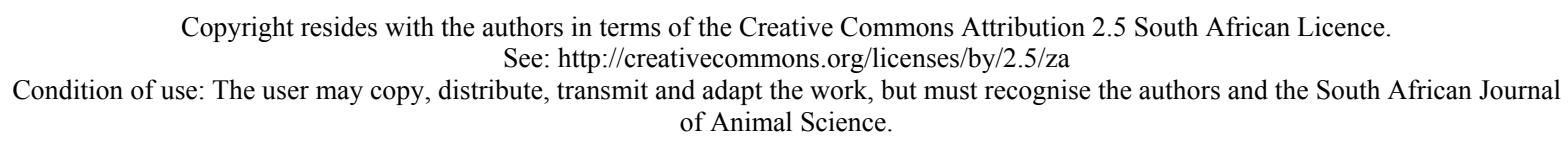

\begin{abstract}
The chemical composition of roughages constantly changes while it grows towards maturity. The effective dry matter (DM), crude protein (CP) and neutral detergent fibre (NDF) degradabilities of lucerne hay (LH), harvested after regrowth periods of 4, 5 or 6 weeks, were determined in ruminally cannulated Holstein and Jersey cows by using the in sacco nylon bag technique. The degradabilities of DM and NDF across breeds differed between the LH harvested after the regrowth periods of 4,5 and 6 weeks. Increasing the regrowth period of LH from 4 to 6 weeks significantly reduced effective DM degradability $\left(\mathrm{k}_{\mathrm{p}}=0.08\right)$ from $59.0 \%$ to $51.2 \%$ and NDF degradability from $30.8 \%$ to $21.2 \%$. Crude protein degradability tended to decrease with advancing maturity, with values of $77 \%, 73 \%$ and $74 \%$ after 4,5 and 6 weeks' regrowth, respectively. Effective degradability of DM, CP and NDF did not differ between Holstein and Jersey cows. The results from this study suggest that LH harvested after a shorter regrowth period is of a higher quality in terms of DM, CP and NDF degradability which decreases as the plants mature.
\end{abstract}

Keywords: Nutrition, forage, Holstein and Jersey cows, alfalfa

${ }^{\#}$ Corresponding author: carelm@elsenburg.com

\section{Introduction}

Forage quality is a complex interrelationship of factors that affects the potential feed intake, nutrient content, digestion, gut fill and passage rate in ruminants (West, 1998). The harvesting stage is the main factor which affects the nutritive value of forages (Linn \& Martin, 1989). Farmers who produce lucerne hay (LH) (Medicago sativa) are faced with a trade-off between dry matter (DM) yield and nutrient composition, because of an inverse relationship between these two traits. Harvesting LH at an early (immature) growth stage, results in high quality forage but in a low DM yield, while delayed harvesting has the opposite effect (Orloff, 1999). As lucerne plants grow, stems become longer while the lower leaves eventually die and fall off, resulting in a reduction of the proportion of leaves in relation to the total plant material. The leaf to stem ratio contributes significantly towards the quality of the lucerne no matter whether it is preserved as hay or silage, because the leaves contain $60 \%$ of the total digestible nutrients (TDN), $70 \%$ of the crude protein (CP) and $90 \%$ of the vitamins (Vough, 2001). As lucerne plants mature the total fibre and lignin contents increase, as observed in higher acid detergent fibre (ADF) and neutral detergent fibre (NDF) levels. Linn \& Martin (1989) observed that for each percentage unit increase in lignin content the digestible DM content is decreased by three to four percentage units. The negative effects associated with LH, harvested at a more mature growth stage, have cost implications for dairy farmers. Feeding a lower quality LH in dairy cow diets necessitates the inclusion of more concentrates to provide sufficient energy and protein in the total diet, thus increasing the feeding cost.

South African data on in sacco protein and fibre degradability values on forages, such as LH, are limited. Erasmus et al. (1990) established a ruminal protein degradation data base for dairy cattle using the in 
sacco polyester bag technique, but values are reported for unspecified LH and dehydrated lucerne meal only. No values have been reported for LH harvested at different growth stages. The fact that the chemical composition of LH changes as the plants mature, necessitates the establishment of NDF and CP degradability values for LH harvested after the different regrowth periods. No information is available on the difference between dairy breeds in terms of the ruminal degradation of LH.

The objectives of this study were to estimate ruminal protein and NDF degradation values for LH harvested after regrowth periods of 4,5 or 6 weeks and to compare the ruminal degradation of LH in Holstein and Jersey cows. The results are expected to expand the existing South African database on ruminal DM, CP and NDF degradation values of feeds.

\section{Materials and Methods}

The study was conducted at the Elsenburg Research Farm of the Western Cape Department of Agriculture. Elsenburg is situated approximately $50 \mathrm{~km}$ east of Cape Town at an altitude of $177 \mathrm{~m}$, longitude of $18^{\circ} 50^{\prime}$ and latitude of $33^{\circ} 51^{\prime}$. Lucerne hay ( $c v$. SA Standard), established on an Oakleaf soil, two years before the start of the present trial, was produced on a 1.5 ha north-facing field. The field was divided into 24 experimental plots of equal size $(15 \times 15 \mathrm{~m})$. The plots were randomly assigned to three treatments in which plant material was harvested after regrowth periods of 4,5 or 6 weeks. Three harvesting cycles were fitted into the period between 20 November 2000 and 26 February 2001. The plots were irrigated once a week with a permanent irrigation system, set with sprinklers $15 \times 15 \mathrm{~m}$ apart, and provided water equivalent to $25 \mathrm{~mm}$ of rain per irrigation session. Before the start of each sampling cycle, the plots were machine-cut at the early blooming stage, after which the LH was harvested following the respective regrowth periods $(4,5$ or 6 weeks). On each harvest date, eight samples of LH were cut from each plot with a hand sickle. To ensure random sampling, a $0.25 \mathrm{~m}^{2}$ wire square was thrown onto the plots and the plant material was cut at a height of $100 \mathrm{~mm}$ where the square landed. Only lucerne material was harvested, carefully avoiding the collection of weeds and grass material. A total of approximately 4 to $6 \mathrm{~kg}$ of wet material was sampled on each harvesting day. In each harvesting cycle, samples were pooled per regrowth period to obtain one representative substrate sample per treatment. The harvested material was dried for $72 \mathrm{~h}$ at $50{ }^{\circ} \mathrm{C}$ in a forceddraught oven after which it was hammer-milled. The material was milled further in a Wiley mill with a $2 \mathrm{~mm}$ screen in preparation for the digestibility trial. After the milling, all the collected material was pooled according to regrowth period. The purpose of the trial was not to evaluate LH over years or seasons, but to get one representative sample per regrowth period.

Four Holstein and four Jersey cows were used in the in situ study. The cows were non-lactating and fitted with rumen cannulae (Beruc, Johannesburg). The cows were individually housed in $4 \times 4 \mathrm{~m}$ stalls in a closed barn with free access to fresh water. Wheat straw was used as bedding and was changed daily. For the duration of the trial the cows received a total mixed ration (TMR) ad libitum (Table 1) that contained 166 $\mathrm{g} / \mathrm{kg}$ of CP, $10.7 \mathrm{MJ} / \mathrm{kg}$ of ME, $327 \mathrm{~g} / \mathrm{kg}$ of NDF, $7.6 \mathrm{~g} / \mathrm{kg}$ of Ca and $4.6 \mathrm{~g} / \mathrm{kg}$ of P, all on a DM basis.

Table 1 Ingredient composition of the total mixed ration used during the trial (values on an air-dried basis)

\begin{tabular}{lc}
\hline Ingredients & $(\mathrm{kg})$ \\
\hline Oat hay & 200 \\
Lucerne hay & 150 \\
Wheat meal (ground) & 328 \\
Maize meal (ground) & 50 \\
Oat grain (ground) & 100 \\
Cotton seed oil cake meal & 150 \\
Limestone & 11 \\
Urea & 6 \\
Salt & 5 \\
\hline
\end{tabular}


Before the start of the in sacco trial, nylon bags $(53 \mu \mathrm{m}$ pore size, Bar Diamond, Inc., Parma, Idaho, USA) were dried in an oven at $100{ }^{\circ} \mathrm{C}$ and transferred to a desiccator. Five grams of substrate DM were then weighed into the bags which were closed with a nylon string and weighed again. The bags were tied to a stainless steel disc, $5 \mathrm{~cm}$ in diameter, $7 \mathrm{~mm}$ thick, weighing $102 \mathrm{~g}$ with 10 evenly-spaced holes drilled near the periphery of the disc, to ensure that the bags remained submerged in the rumen contents during incubation. The discs were tied to the lid of the cannula with a nylon string, $500 \mathrm{~mm}$ in length, allowing the bags to move freely with the ruminal contents. Nine bags, each representing the different incubation periods of $2,4,8,16,24,48$ and 72 hours were placed in the rumen of each cow (NRC, 2001). The bags were inserted in reverse order of removal, i.e. bags that were to be incubated for 72 hours were inserted in the rumen on the first day at 14:00. The rest of the bags were inserted on the following days according to the incubation schedule. All the bags were removed simultaneously at 14:00 on the fourth day. It was expected that, for incubation periods longer than 24 hours, not enough residue would remain for all the chemical analyses, thus duplicate bags were prepared for the 48 and 72 hours incubation times.

Upon removal from the rumen, the bags were placed in ice water to stop microbial activity, followed by rinsing under running tap water. All the bags were then washed in cold water for 10 minutes in a twin-tub washing machine using the gentle cycle (Erasmus \& Prinsloo, 1988). The water was drained after five minutes of washing and the bags were then washed in fresh water for another five minutes. Bags containing feed samples not subjected to ruminal incubation $(0 \mathrm{~h})$, were washed in the same way. After washing, the bags were dried at $60{ }^{\circ} \mathrm{C}$ for 48 hours to determine the residual DM. The forage residues were removed from the bags and ground, using a Cyclotec mill with a $1 \mathrm{~mm}$ sieve (Nocek \& Grant, 1987). The contents of duplicate bags ( 48 and $72 \mathrm{~h}$ ) were pooled before being milled. Samples of the initial feeds and residues from the bags were analyzed for CP according to the methods of the AOAC (1984). The NDF content was determined with the ANKOM200 fibre analyzer (ANKOM Technology Corporation, Fairport, New York, USA). The DM, N and NDF disappearance values were fitted to the following non-linear model (Ørskov \& McDonald, 1979):

$$
Y=a+b\left(1-e^{-c t}\right), \text { where }
$$

$Y=$ amount degraded at time $t$ and $a, b$ and $c=$ non-linear parameters estimated by an iterative least square procedure. Parameter $a$ represents the soluble and readily degradable fraction, $b$ the potentially degradable fraction and $c$ the rate at which $b$ is degraded.

By introducing the fractional outflow rate $k$, the effective degradabilities $(\mathrm{P})$ were calculated from the following equation (Ørskov \& McDonald, 1979):

$$
\mathrm{P}=a+\frac{b c}{c+k}
$$

Flow rates $(k)$ of 0.05 and 0.08 per hour were used as suggested by Erasmus et al. (1990). Rumen fluid samples were collected from the rumen 1 hour before feeding, as well as 2 and 5 hours after feeding. The $\mathrm{pH}$ of the rumen fluid was measured immediately after collection with a portable $\mathrm{pH}$ meter.

The non-linear parameters $a, b$ and $c$ were estimated by least-square iterations using the N-LIN procedure of SAS (1996). A one-way analysis of variance (Snedecor \& Cochran, 1991) was performed on the data using Statgraphics (1985). Significance was declared at $P \leq 0.05$, unless otherwise indicated. Multiple range tests were used to separate least-square means at $P \leq 0.05$.

\section{Results and Discussion}

The CP content of the LH used in the current trial (Table 2) was higher than the values indicated in the NRC (1989) tables for LH in the late vegetative, early blooming and mid-blooming growth stages. This may be related to the fact that, in the current study, $\mathrm{LH}$ samples were dried at $50{ }^{\circ} \mathrm{C}$ directly after harvesting. This probably prevented the loss of leaves, something that is normally observed in field drying. According to the NRC (1989), CP values for finely-ground LH meal and mid-maturity LH cubes were 192 and $195 \mathrm{~g} / \mathrm{kg}$, respectively, which correspond to the $\mathrm{CP}$ values of LH harvested after the five weeks regrowth period in the current study. 
The CP content of the LH harvested after the regrowth periods of 4, 5 and 6 weeks agree with values reported by Gray (2001) for LH described as late budding, early blooming and blooming stages, viz. 217, 192 and $176 \mathrm{~g} / \mathrm{kg}$, respectively. Balde et al. (1993) also reported a reduction in CP content (232 to $183 \mathrm{~g} / \mathrm{kg}$ ) and an increase in NDF content (397 to $477 \mathrm{~g} / \mathrm{kg}$ ) of LH maturing from early blooming to full bloom.

Table 2 The crude protein and neutral detergent fibre content of lucerne hay harvested after regrowth periods of 4, 5 and 6 weeks (except for dry matter, values are on a dry matter basis)

\begin{tabular}{llll}
\hline \multirow{2}{*}{ Item } & \multicolumn{3}{c}{ Regrowth period (weeks) } \\
\cline { 2 - 4 } & 4 & 5 & 6 \\
\hline Dry matter $(\mathrm{g} / \mathrm{kg})$ & 920 & 900 & 910 \\
Crude protein $(\mathrm{g} / \mathrm{kg})$ & 221 & 193 & 180 \\
Neutral detergent fibre $(\mathrm{g} / \mathrm{kg})$ & 397 & 460 & 440 \\
\hline
\end{tabular}

The effect of cow breed on the non-linear parameters $a, b$ and $c$ for the estimated ruminal DM, CP and NDF disappearance values of LH, harvested at different growth stages is presented in Table 3 . The $a$-values were similar for Holsteins and Jerseys as it is a function of the feed and not influenced by animal factors. The potential degradability values $(b)$ for DM, CP and NDF did not differ between the two breeds for any of the regrowth periods. Similarly, the rate of DM, CP and NDF degradation (c) did not differ between Holstein and Jersey cows for any of the regrowth periods.

Table 3 The effect of cow breed on the estimated rumen disappearance values of dry matter (DM), crude protein $(\mathrm{CP})$ and neutral detergent fibre (NDF) of lucerne hay harvested after the regrowth periods of 4, 5 and 6 weeks. Values are shown as percentages

\begin{tabular}{|c|c|c|c|c|c|c|c|c|c|}
\hline \multirow{3}{*}{ Nutrient } & \multicolumn{8}{|c|}{ Regrowth period (weeks) } & \multirow[b]{3}{*}{$P$} \\
\hline & \multicolumn{3}{|c|}{4} & \multicolumn{3}{|c|}{5} & \multicolumn{2}{|c|}{6} & \\
\hline & Holstein & Jersey & $P$ & Holstein & Jersey & $P$ & Holstein & Jersey & \\
\hline \multicolumn{10}{|c|}{ Dry matter } \\
\hline$a$ & 28.87 & 28.87 & - & 26.06 & 26.06 & - & 30.86 & 30.86 & - \\
\hline$b$ & 46.19 & 46.38 & 0.17 & 44.61 & 44.54 & 0.97 & 37.31 & 38.16 & 0.55 \\
\hline$c$ & 0.17 & 0.17 & 0.96 & 0.12 & 0.14 & 0.40 & 0.10 & 0.10 & 1.00 \\
\hline \multicolumn{10}{|c|}{ Crude protein } \\
\hline$a$ & 37.20 & 37.20 & - & 37.32 & 37.32 & - & 35.44 & 35.44 & - \\
\hline$b$ & 55.15 & 54.97 & 0.75 & 54.05 & 54.38 & 0.57 & 53.71 & 53.67 & 0.97 \\
\hline$c$ & 0.23 & 0.21 & 0.71 & 0.14 & 0.15 & 0.68 & 0.19 & 0.23 & 0.40 \\
\hline \multicolumn{10}{|c|}{ Neutral detergent fibre } \\
\hline$a$ & 7.30 & 7.30 & - & 15.00 & 15.00 & - & 13.96 & 13.96 & - \\
\hline$b$ & 45.47 & 44.61 & 0.80 & 42.39 & 43.75 & 0.65 & 40.31 & 38.39 & 0.89 \\
\hline$c$ & 0.17 & 0.09 & 0.49 & 0.15 & 0.12 & 0.44 & 0.03 & 0.03 & 1.00 \\
\hline
\end{tabular}

$a$ - soluble fraction; $b$ - potentially degradable fraction; $c$ - rate at which $b$ is degraded. 
The disappearance values for the different regrowth periods across breeds are presented in Table 4 .

Table 4 The effect of regrowth period of lucerne hay on the soluble fraction $(a)$, potentially degradable fraction $(b)$ and rate of degradation $(c)$ for dry matter (DM), crude protein $(\mathrm{CP})$ and neutral detergent fibre (NDF) disappearance (\%) from the rumen. Values with different superscripts differ significantly at $P \leq 0.05$

\begin{tabular}{|c|c|c|c|c|c|}
\hline \multirow{2}{*}{ Component } & \multicolumn{3}{|c|}{ Regrowth period (weeks) } & \multirow{2}{*}{ SEM } & \multirow{2}{*}{$P$} \\
\hline & 4 & 5 & 6 & & \\
\hline \multicolumn{6}{|l|}{ Dry matter } \\
\hline$a$ & $28.87^{\mathrm{a}}$ & $26.06^{\mathrm{b}}$ & $30.86^{\mathrm{c}}$ & - & $<0.01$ \\
\hline$b$ & $46.28^{\mathrm{a}}$ & $44.58^{\mathrm{a}}$ & $37.74^{\mathrm{b}}$ & 0.41 & $<0.01$ \\
\hline$c$ & $0.17^{\mathrm{a}}$ & 0.13 & $0.10^{\mathrm{b}}$ & 0.01 & 0.01 \\
\hline \multicolumn{6}{|c|}{ Crude protein } \\
\hline$a$ & $37.20^{\mathrm{a}}$ & $37.32^{\mathrm{b}}$ & $35.44^{\mathrm{c}}$ & - & $<0.01$ \\
\hline$b$ & $55.06^{\mathrm{a}}$ & $54.22^{\mathrm{ab}}$ & $53.69^{b}$ & 0.17 & 0.02 \\
\hline$c$ & $0.22^{\mathrm{a}}$ & $0.15^{\mathrm{b}}$ & $0.21^{\mathrm{a}}$ & 0.01 & 0.01 \\
\hline \multicolumn{6}{|c|}{ Neutral detergent fibre } \\
\hline$a$ & $7.30^{\mathrm{a}}$ & $15.00^{\mathrm{b}}$ & $13.96^{\mathrm{c}}$ & - & $<0.01$ \\
\hline$b$ & 45.04 & 43.07 & 39.36 & 2.24 & 0.58 \\
\hline$c$ & $0.13^{\mathrm{a}}$ & $0.14^{\mathrm{a}}$ & $0.03^{\mathrm{b}}$ & 0.02 & 0.07 \\
\hline
\end{tabular}

$a$ - soluble fraction; $b$ - potentially degradable fraction; $c$ - rate at which material is degraded.

If the chemical composition and degradation values change as plants mature, one would expect results of the 5 weeks' regrowth samples to be intermediate between the 4 and 6 weeks' regrowth values. This was, however, not always the case. One reason may be related to the fact that the respective harvesting sequences occurred during three separate cycles over the growing season and that the samples were pooled per regrowth period. Furthermore, one-week time intervals might be too short to accurately reflect chemical changes and degradation characteristics over time. For this reason, where the 5 weeks' regrowth results were not intermediate between the 4 and 6 weeks' results, only the 4 and 6 weeks' results will be discussed, as these would reflect the maturing effects more accurately. All the results are, however, indicated in the tables.

The soluble DM fractions ( $a$-value) increased $(P<0.01)$, whereas the soluble CP fraction decreased $(P<0.01)$ from 4 to 6 weeks' regrowth periods. While the decrease in the soluble CP fraction is probably related to the increase in the NDF-content of the hay, the increase in the apparent soluble NDF fraction may be an artifact of model fitting or possibly a sample aberration or it may be related to material washout losses from the Dacron bags. Savoie et al. (1999) determined zero-time disappearance values by washing the bags in cold water until the rinsing water was clear. These authors found a soluble DM fraction (30.7\%) for chopped lucerne similar to the 6 weeks' regrowth value observed for LH in the current study. The soluble CP value reported by these authors (36.4\%) is comparable with the $a$-values in the current experiment for all the LH treatments.

The potential $\mathrm{DM}$ and $\mathrm{CP}$ degradabilities $(b$-values) differed $(P<0.05)$ between treatments and decreased as plants matured. A potential DM degradability value of approximately $48 \%$ was reported by Savoie et al. (1999) for chopped LH, which corresponds with the 4 weeks' regrowth value obtained in the current study. The same authors reported a CP degradability value of $57.8 \%$, which is somewhat higher than the values in the current study.

The potential NDF degradability did not differ between treatments. Savoie et al. (1999) reported a $b$-value of $51.8 \%$ for LH ( $420 \mathrm{~g} / \mathrm{kg} \mathrm{NDF})$ that was wilted for four hours. The rumen $\mathrm{pH}$ in the current study was generally low and varied between 5.6 to 5.8 for Holsteins and 5.6 to 5.7 for Jerseys from one hour 


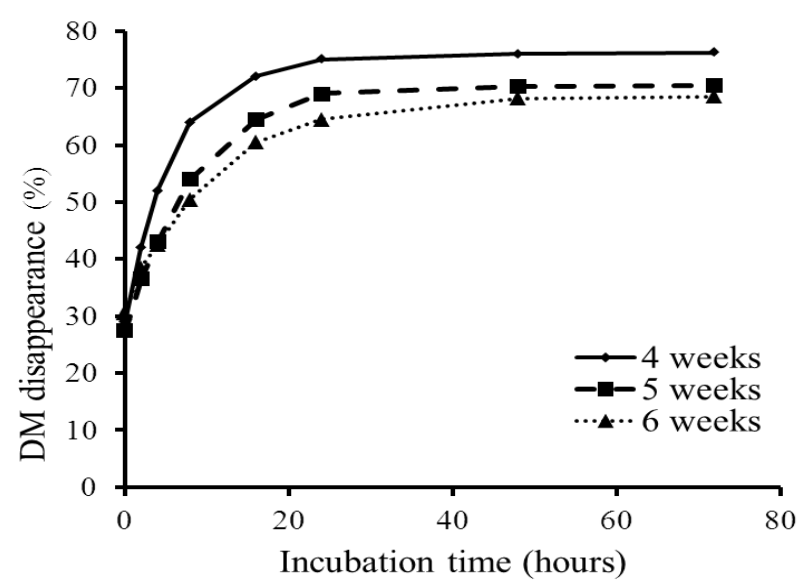

Figure 1 (a) Average ruminal dry matter (DM) disappearance, in Holstein and Jersey cows, of lucerne hay harvested after regrowth periods of 4, 5 and 6 weeks.

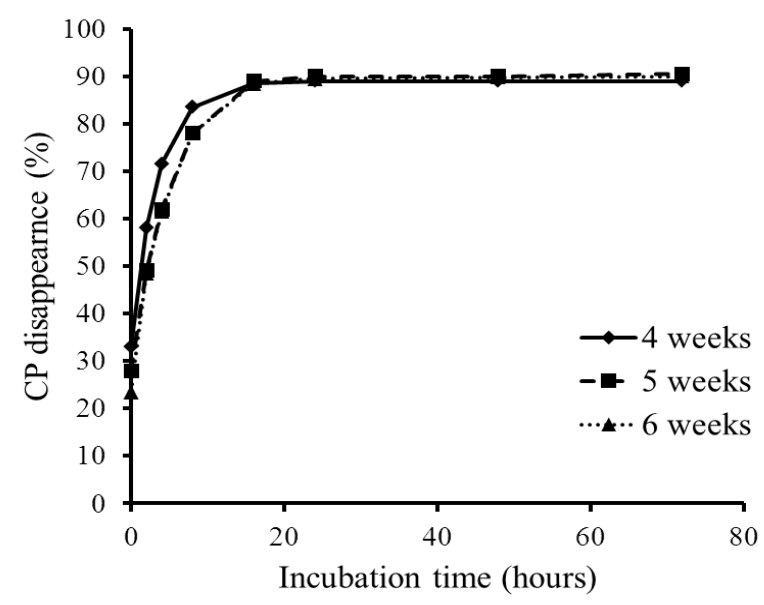

Figure 1 (b) Average ruminal crude protein (CP) disappearance, in Holstein and Jersey cows, of lucerne hay harvested after regrowth periods of 4,5 and 6 weeks.

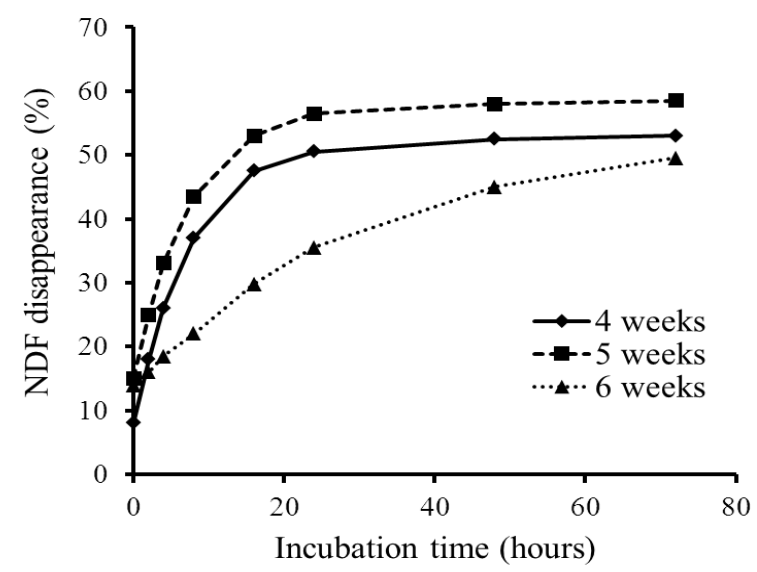

Figure 1 (c) Average ruminal neutral detergent fibre (NDF) disappearance, in Holstein and Jersey cows, of lucerne hay harvested after regrowth periods of 4,5 and 6 weeks. 
before feeding to five hours after feeding. This could have resulted in the lower $b$-values compared to those reported by Savoie et al. (1999). It should also be kept in mind that, although the cows were non-lactating, they received a diet typical for lactating cows to simulate rumen conditions.

The rate of degradation ( $c$-values) for DM, CP and NDF differed between the LH harvested after the regrowth periods of 4, 5 and 6 weeks (Table 4 and Figures 1a, 1b and 1c). The rate of DM degradation was highest for LH harvested after the 4 weeks' regrowth period and the lowest for LH harvested after the 6 weeks' regrowth period. Lucerne hay harvested after the 5 weeks regrowth period showed the lowest rate of protein degradation, while LH harvested after the 6 weeks regrowth period had the lowest NDF degradation rate. In Figure 1, the low rate of NDF degradation of LH harvested after the 6-week regrowth period is evident. A faster rate of protein degradation $(\mathrm{c}=0.32)$ was reported by Savoie et al. (1999) which could probably be explained by the fact that the LH was crushed during harvesting in their experiment.

The effective degradability values of DM, CP, and NDF did not differ between Holstein and Jersey cows for the LH harvested after the regrowth periods of 4, 5 and 6 weeks (Table 5).

Table 5 The effective degradability (\%) for dry matter (DM), crude protein (CP) and neutral detergent fibre (NDF) at fractional outflow rates of 0.05 and $0.08 / \mathrm{h}$ for Holstein and Jersey cows

\begin{tabular}{cccccccccc}
\hline & \multicolumn{7}{c}{ Regrowth period (weeks) } \\
\cline { 2 - 10 } Component & \multicolumn{7}{c}{5} & \multicolumn{7}{c}{5} & & \\
\cline { 2 - 10 } & Holstein & Jersey & $P$ & Holstein & Jersey & $P$ & Holstein & Jersey & $P$ \\
\hline Dry matter & & & & & & & & & \\
$0.05 / \mathrm{h}$ & 63.12 & 64.59 & 0.46 & 57.12 & 58.61 & 0.18 & 55.01 & 55.71 & 0.59 \\
$0.08 / \mathrm{h}$ & 58.74 & 60.29 & 0.54 & 52.38 & 54.09 & 0.16 & 50.88 & 51.47 & 0.70 \\
$\begin{array}{c}\text { Crude protein } \\
0.05 / \mathrm{h}\end{array}$ & 81.72 & 81.28 & 0.85 & 77.18 & 78.23 & 0.45 & 77.63 & 79.43 & 0.26 \\
$0.08 / \mathrm{h}$ & 77.22 & 76.62 & 0.84 & 71.79 & 72.95 & 0.47 & 72.89 & 75.15 & 0.31 \\
Neutral detergent fibre & & & & & & & & \\
$0.05 / \mathrm{h}$ & 35.82 & 35.12 & 0.84 & 45.49 & 45.89 & 0.86 & 23.18 & 24.75 & 0.25 \\
$0.08 / \mathrm{h}$ & 32.03 & 30.04 & 0.62 & 41.26 & 41.29 & 0.99 & 20.61 & 21.77 & 0.39 \\
\hline
\end{tabular}

The data from Holstein and Jersey cows was pooled to obtain effective degradability values (Table 6). The effective DM, CP, and NDF degradabilities differed between LH harvested at different stages of maturity at both outflow rates of 0.05 and $0.08 / \mathrm{h}$. The highest effective DM degradability was found for LH harvested after a 4-week regrowth period (63.9\%) and degradability decreased as the LH matured $(57.9 \%$ and 55.4\%), respectively, for LH harvested after regrowth periods of 5 and 6 weeks. Balde et al. (1993) found similar DM degradability values if their data is recalculated for a passage rate of $0.05 / \mathrm{h}$. Their DM degradability values were calculated to be $66.3 \%, 60.9 \%$ and $58.4 \%$, respectively, for LH cut in early, mid and full bloom.

Protein degradability decreased as the regrowth period of LH increased from 4 to 5 weeks, after which it remained constant. A decrease in CP degradability associated with the maturing of LH was also observed by Hoffman et al. (1993). They found that LH harvested in a late vegetative and late budding stage had rumen degradable CP values of $84 \%$ and $77 \%$, respectively. A similar decrease in CP degradability was found by Balde et al. (1993). Their CP degradability values were calculated at a flow rate of $0.03 / \mathrm{h}$, giving values of $85 \%, 84 \%$ and $80 \%$ for LH cut at early budding, early blooming and full bloom, respectively. Recalculating their values, assuming a flow rate of $0.05 / \mathrm{h}$, values of $81.7 \%, 76.6 \%$ and $77.2 \%$ were obtained, which agree with the values in the current study for LH harvested after the regrowth periods of 4, 5 and 6 weeks. Protein degradability values of $78.8 \%$ and $75.0 \%$ were found by Erasmus et al. (1990), at outflow rates of $0.05 / \mathrm{h}$ and $0.08 / \mathrm{h}$, respectively. Chiou et al. (1995) reported protein degradability values of $78.0 \%$ 
and $72.0 \%$ at outflow rates of 0.05 and $0.08 / \mathrm{h}$ for $\mathrm{LH}$. These values are comparable with the values found in the current study.

Table 6 The effective degradability percentage ( $P$-values) for dry matter, crude protein and neutral detergent fibre at fractional outflow rates of 0.05 and $0.08 / \mathrm{h}$ for lucerne hay harvested after regrowth periods of 4, 5 and 6 weeks. Values with different superscripts differ significantly $(P \leq 0.05)$.

\begin{tabular}{cccccc}
\hline \multirow{2}{*}{ Component } & \multicolumn{3}{c}{ Regrowth period (weeks) } & SEM & $P$ \\
\cline { 2 - 3 } & 4 & 5 & 6 & & \\
\hline Dry matter & & & & & \\
$0.05 / \mathrm{h}$ & $63.9^{\mathrm{a}}$ & $57.9^{\mathrm{b}}$ & $55.4^{\mathrm{c}}$ & 0.4 & $<0.01$ \\
$0.08 / \mathrm{h}$ & $59.0^{\mathrm{a}}$ & $53.2^{\mathrm{b}}$ & $51.2^{\mathrm{b}}$ & 0.5 & $<1.01$ \\
& & & & & \\
Crude protein & & & & & \\
$0.05 / \mathrm{h}$ & $81.5^{\mathrm{a}}$ & $77.7^{\mathrm{b}}$ & $78.5^{\mathrm{ab}}$ & 0.5 & 0.01 \\
$0.08 / \mathrm{h}$ & $76.9^{\mathrm{a}}$ & $73.00^{\mathrm{b}}$ & $74.0^{\mathrm{ab}}$ & 0.7 & 0.06 \\
& & & & & \\
Neutral detergent fibre & & & & \\
$0.05 / \mathrm{h}$ & $35.5^{\mathrm{a}}$ & $45.7^{\mathrm{b}}$ & $23.7^{\mathrm{c}}$ & 0.6 & $<0.01$ \\
$0.08 / \mathrm{h}$ & $30.7^{\mathrm{a}}$ & $41.3^{\mathrm{b}}$ & $21.2^{\mathrm{c}}$ & 0.7 & $<0.01$ \\
\hline
\end{tabular}

The lucerne hay harvested after the 5-week regrowth period had the highest NDF degradability. This was unexpected and is not readily explicable. The NDF content of the lucerne was also higher for the 5-week regrowth period than for any of the other two regrowth periods. This might be ascribed to the differences in the stem to leaf ratio as the plant matures. It is speculated that the decrease in NDF degradability, observed for the six weeks regrowth stage, was due to lignification. Hoffman et al. (1993) also found a decrease in rumen degradable NDF content of LH harvested at a late vegetative, late budding and mid-blooming stage. The rumen degradable NDF values for LH harvested at these growth stages were $47.9 \%, 32.0 \%$ and $28.6 \%$, respectively. Smith et al. (1972) stated that the effects on forage digestibility are associated with the increase in forage NDF content and an increase in the lignification of the NDF. It would, therefore, not be improbable to believe that the total nutrient utilization would be negatively affected by a decrease in rumen NDF digestibility. These results indicated that LH harvested at an earlier growth stage would be of better quality in terms of effective DM, CP and NDF degradability and that the degradability tends to decrease as the LH matures.

\section{Conclusion}

The chemical composition of the LH changed with the increasing regrowth periods of four to six weeks. The CP content decreased and the NDF content increased as the regrowth period increased, suggesting a decrease in nutritive value. This was confirmed by results from the in situ rumen digestibility trial that showed that a longer regrowth period of LH decreased the effective DM, CP and NDF degradability values. The reduction in rumen degradability associated with the maturation of the LH could have a negative effect on the performance of dairy cows as microbial CP production may be reduced because of the reduction in the fermentability of the forage. The results from this study indicate that the DM, CP and NDF degradability of LH was higher after a regrowth period of 4 weeks compared to a 6-week regrowth period. The effective degradability (\%) for DM, CP and NDF, at fractional outflow rates of 0.05 and $0.08 / \mathrm{h}$, did not differ between Holstein and Jersey cows. 


\section{References}

AOAC, 1984. Official Methods of Analysis (14th ed.). Association of Official Analytical Chemists. Washington, D.C., USA.

Balde, A.T., Vandersall, J.H., Erdman, R.A., Reeves, J.B. \& Glenn, B.P., 1993. Effect of stage of maturity of alfalfa and orchardgrass on in situ dry matter and crude protein degradability and amino acid composition. Anim. Feed Sci. Technol. 44, 29-43.

Chiou, P.W., Chen, K., Kuo, K., Hsu, J. \& Yu, B., 1995. Studies on the protein degradabilities of feedstuffs in Taiwan. Anim. Feed Sci. Technol. 55, 215-226.

Erasmus, L.J., Prinsloo, J. \& Meissner, H.H., 1988. The establishment of a protein degradability data base for dairy cattle using the nylon bag technique. 1. Protein sources. S. Afr. J. Anim. Sci. 18, 23-29.

Erasmus, L.J., Prinsloo, J., Botha, P.M. \& Meissner, H.H., 1990. Establishment of a ruminal protein degradation data base for dairy cattle using the in situ polyester bag technique. 2. Energy sources. S. Afr. J. Anim. Sci. 20, 124-129.

Gray, A.M., 2001. Hay quality and marketing in the Rocky Mountain Front Range and High Plains. University of Wyoming, College of Agriculture, Coop. Ext. Serv., USA.

Hoffman, P.C., Sievert, S.J., Shaver, R.D., Welch, D.A. \& Combs, D.K., 1993. In situ dry matter, protein and fibre degradation of perennial forages. J. Dairy. Sci. 76, 2632-2643.

Linn, J.G. \& Martin, N.P., 1989. Forage quality tests and interpretations. http://www.extension.umn.edu/distribution/livestocksystems/DI2637.html, accessed October 2008.

Nocek, J.E. \& Grant, A.L., 1987. Characterization of in situ nitrogen and fibre digestion and bacterial nitrogen contamination of haycrop forages preserved at different dry matter percentages. J. Anim. Sci. 64, 552-564.

National Research Council, 1989. Nutrient requirements of dairy cattle (6th revised ed., Update, 1989). National Academy Press, Washington, D.C., USA.

National Research Council, 2001. Nutrient requirements of dairy cattle (7th revised ed., Update, 2001). National Academy Press, Washington, D.C., USA.

Orloff, S., 1999. Selecting cutting schedules - the yield and quality tradeoff. Hoard's Dairyman. 144, 493.

Ørskov, E.R. \& McDonald, I., 1979. The estimation of protein degradability in the rumen from incubation measurements weighted according to rate of passage. J. Agric. Sci., Camb. 92, 499-503.

SAS, 1996. User's guide: Statistics, Version 6.12. SAS Inst., Inc., Cary, N.C., USA.

Savoie, P., Tremblay, G.F. \& Petit, H.V., 1999. Ruminal degradability of alfalfa and corn after processing or maceration. Can. J. Anim. Sci. 79, 361-368.

Smith, L.W., Goering, H.K. \& Gordon, C.H., 1972. Relationships of forage compositions with rates of cell wall digestion and indigestibility of cell walls. J. Dairy. Sci. 55, 1140-1147.

Snedecor, G.W. \& Cochran, W.G., 1991. Statistical Methods (7th ed.). Iowa State Univ. Press, Ames, Iowa.

Statgraphics, 1985. Statistical Graphics System. Statistical Graphics Corporation, USA.

Vough, L., 2001. Evaluating hay quality. http://www.agnr.umd.edu/ces/pubs/html/fs644.htm, accessed August 2008.

West, J.W., 1998. Factors which influence forage quality and effectiveness in dairy rations. http://www.afns.ualberta.ca/wcds/wcd98/ch13.htm, accessed: September 2008. 